\title{
Agenciamientos en las sociedades de control ${ }^{1}$
}

\author{
Assemblages in societies of control \\ Luis Sebastián Rossi \\ Universidad Nacional de Entre Ríos, Argentina
}

\begin{abstract}
RESUMEN El objetivo de este artículo es presentar las principales tesis detrás de la teoría de Gilles Deleuze y Félix Guattari sobre la aparición de las formaciones sociales de control y sobre los agenciamientos que a ellas corresponden. Así, se recorrerán tres tesis fundamentales sobre la mutación del capitalismo contemporáneo. En el primer apartado se abordarán las transformaciones en las relaciones de poder y en las formaciones de saber. En el segundo, nos detendremos en los cambios en los modos de subjetivación (de la sujeción social a la esclavitud maquínica). Por último, exploraremos los nuevos regímenes de imágenes y de signos que nuestros autores hicieron corresponder con las sociedades contemporáneas. No obstante, ninguna de estas transformaciones es legible, para la teoría social crítica deleuzoguattariana, sin los agenciamientos concretos en los que tienen lugar. Por ello abordaremos algunos ejemplos de componendas de la computación ubicua que ilustrarán las dimensiones de las nuevas vías de modulación (codificación) del poder contemporáneo y de agenciamientos massmediáticos que aseguran formas novedosas de reterritorializaciones por medios artificiales (territorialización). Hacia el final nos detendremos en el dato primario de toda formación social, sus posibles líneas de fuga.
\end{abstract}

PALABRAS CLAVE Agenciamientos massmediáticos y de computación ubicua; teoría deleuzoguattariana; sociedades de control.

1. La fuente de financiamiento del presente artículo surge de becas doctorales y postdoctorales otorgadas por CONICET. El trabajo recupera los aportes del proyecto en ejecución llamado "Agenciamientos de computación ubicua y modos de subjetivación en las sociedades contemporáneas. De la modulación a las reterritorializaciones artificiales" (Res. 3314 CONICET, ejecutado en CISPOFCEdu-UNER). CONICET: Consejo Nacional de Investigaciones Científicas y Técnicas (Argentina). CISPO-FCEdu-UNER: Centro de Investigaciones Sociales y Políticas, Facultad de Ciencias de la Educación, Universidad Nacional de Entre Ríos (Argentina). 
ABSTRACT This paper approaches the main thesis behind Deleuze and Guattari's theory about the rise of social formations of control and their assemblages [agencements]. To achieve such aim, three theses on mutation of contemporary capitalism will be presented. Firstly, this study focuses on the transformations of power relations and knowledge formation. Secondly, attention is turned to understanding the changes in modes of subjectivation (from social subjection to machinic enslavement). Thirdly, the paper will explore the new regimes of images and signs of our contemporary societies. However, none of these transformations can be understood, for deleuzoguattarian critical social theory, without reference to the concrete assemblages [agencements] in which they take place. For this reason, on the one hand, this article will analyze some examples of ubiquitous computations that illustrate the dimensions of the new modulation strategies (codification) of contemporary power. On the other hand, this study will explore the mass media assemblages that assure new forms of reterritorialization by artificial means (territorialization) and, finally, it will focus on the possible lines of flight of social formation of control.

KEYWORDS Deleuzoguattarian theory, societies of control, assemblages of ubiquitous computations and mass media assemblages.

\section{Introducción}

A principios de la década de 1990, tanto Félix Guattari como Gilles Deleuze terminan de dar forma a problemas originales y derivados de sus trabajos conjuntos. Entre ellos, uno de los tópicos recurrentes será el argumento que sugiere profundas mutaciones en el capitalismo contemporáneo, cuyo epílogo lo conformaría la emergencia de las formaciones sociales del control. La fuerza heurística de tal hipótesis fecundó innumerables comentarios y análisis que convirtieron a la inspiración deleuziana (y guattariana) en bibliografía de referencia. No obstante, y a pesar de la popularidad de estos escritos, las aristas fundamentales de la teoría social crítica que esculpió la hipótesis antedicha permanecieron en el olvido.

Sin intentar saldar aquí todas las deudas con el trabajo de los autores, presentaremos una serie de tesis sobre las mutaciones en las formaciones sociales contemporáneas presupuestas por los filósofos franceses respecto de lo que concebían como el ascenso de una axiomática capitalista. Por supuesto, la complejidad de la filosofía deleuzoguattariana excede los límites de una pieza como la actual, por ello apelaremos al artilugio de reconstruir una visión de conjunto del argumento, a sabiendas de que cada sector del mismo puede ser explorado por derecho propio. Indagaremos así tres tesis fundamentales para comprender la noción de sociedades de control. Primero, 
nos abocaremos a las transformaciones en las formaciones de saber y en las relaciones de poder, luego nos detendremos en los cambios en los modos de subjetivación (forjados en el péndulo entre sujeción social y esclavitud maquínica) y, por último, exploraremos el surgimiento de un nuevo régimen de signos y de imágenes.

A partir de allí, profundizaremos en las mutaciones en el capitalismo contemporáneo a través de la noción concreta de agenciamiento. El parcial olvido de dicho concepto, cuando se consideran los problemas relacionados a las formaciones sociales del control, ha generado un empobrecimiento de las dimensiones ontogenéticas, estéticas y políticas que atraviesan la teoría crítica deleuzoguattariana. No obstante, reconstruir su centralidad para estos problemas no nos llevará a un abordaje más amplio de las teorías generales de los agenciamientos construidas, por lo general, bajo la voz inglesa assemblages ${ }^{2}$ (ensamblajes). Como ha sido estudiado por Buchanan (2015) y Phillips (2006) el concepto de ensamblaje tiene un campo semántico mayor que el de agenciamiento e implica modelos que reparan en la complejidad, la agregación de actos, la heterogeneidad, la agencia no-humana, el carácter de anastomosado de algún fenómeno, etc ${ }^{3}$. No obstante, siguiendo las recepciones latinoamericanas, francesas e italianas (y a los citados críticos angloparlantes) nosotros preferimos, de modo más restringido, enfocarnos en la especificidad del problema en el marco de la teoría deleuzoguattariana. Esto es, abordaremos primero las transformaciones en las relaciones de poder, en las formaciones de saber (II) y en los modos de subjetivación (III) en el capitalismo contemporáneo para, a partir de allí, identificar algunos agenciamientos específicos de las formaciones sociales del control (IV, V y VI).

Como puede verse en Fourquet y Murard (1978), la noción de agenciamiento deleuzoguattariana nace alrededor del problema del poder de Foucault, en el contexto de una crítica al capitalismo contemporáneo (o axiomática). No obstante, a diferencia del filósofo de Las palabras y las cosas, para Deleuze y Guattari el dato primario de las formaciones sociales es el flujo o campo de deseo ${ }^{4}$ que conecta prácticas (discursivas y no discursivas) segmentadas, estratificadas y regularizadas en relaciones de poder (Patton, 2013; Sauvagnargues, 2006).

2. De allí que en el resumen en inglés hayamos remitido al término francés.

3. Buchanan (2015) subraya que las derivas conceptuales detrás de "assemblage" exceden a las de agenciamiento en el sentido deleuzoguattariano, de allí que se dedique exhaustivamente a la crítica de diversas vertientes interpretativas. Un caso paradigmático es el de DeLanda quien construye su propia teoría estudiando características de los ensamblajes como una manera original de pensar las relaciones exteriores a los términos, las propiedades emergentes de su conjugación, la expresividad, la materialidad, la relación parte-todo, la causalidad no lineal, la contingencia, etc. Sin embargo, en sintonía con los modelos generales de los ensamblajes, DeLanda, a diferencia de Deleuze y Guattari, no estructura la noción en el marco de un aparato crítico de las formaciones sociales capitalistas.

4. Como sostiene Sauvagnargues (2006) el deseo para Deleuze y Guattari antes que estructural (figurativo, imaginario, significante, etc.) está perpetuamente maquinado, abierto, conectado, circulando en múltiples líneas que constituyen un plano de inmanencia. 
Así, de acuerdo a la famosa síntesis deleuziana, todo agenciamiento conecta cuatro dimensiones: estados de cosas, enunciaciones, territorios y movimientos de desterritorialización por donde fluye el deseo. No obstante, una componenda no es una mera unión transitoria de elementos heterogéneos fácilmente desarmable (Pardo, 2011), sino un mixto complejo de fuerzas materiales y simbólicas que suponen dimensiones genealógicas entrelazadas. Por ello, para Sibertin-Blanc (2013) se trata de un nuevo materialismo histórico-maquínico (rizomático, diría Buchanan).

Así, Deleuze y Guattari (1997) definirán a los agenciamientos como multiplicidades de elementos heterogéneos, históricamente determinables y variables que, como veremos en las páginas a seguir, se ven arrastrados por dos ejes en movimiento helicoidal: uno horizontal de codificación o estratificación de las formas y uno vertical o de territorialización/desterritorialización de las sustancias 5 . Al mismo tiempo, las componendas $^{6}$ son atravesadas por múltiples líneas (molares, moleculares y abstractas) identificables en sus dos caras: agenciamientos maquínicos de cuerpos, pasiones y acciones que reaccionan unos con otros $(A M C)$ y agenciamientos colectivos de enunciación y actos (ACE). Estas líneas abren a dichas componendas a las máquinas $\operatorname{abstractas}^{7} \mathrm{o}$ al diagrama de relaciones de fuerzas propias de las formaciones sociales a las que pertenecen y las ponen en contacto con distintos regímenes de signos, maquinismos socio-técnicos (filums o formaciones de potencia) y modos de subjetivación (Guattari, 2015, 2017).

En las secciones cuarta y quinta abordaremos los movimientos de codificación que se corresponden con el nuevo poder de modulación o de control y las (re)territorializaciones que aseguran o estabilizan los pequeños ritmos sociales de las componendas del Capitalismo Mundial Integrado o Integrante (CMI). Gracias a ello nos detendremos en algunos ejemplos característicos de la teoría deleuzoguattariana relevantes para los estudios sobre las transformaciones que viven nuestras sociedades contemporáneas ${ }^{8}$.

5. Distinción que no es equivalente a la discriminación entre significado y significante, estructura y superestructura, etc.

6. Tomaremos como sinónimos, siguiendo los ensayos de traducción de Pardo (2011), a la noción de agenciamiento y a la de componenda.

7. Un ejemplo de este concepto, como veremos, es el foucaultiano del panoptismo (similar a Rostridad).

8. Como nos ha sugerido uno de los evaluadores, existen múltiples pasajes entre las sociedades disciplinarias y las formaciones del control antes que un total reemplazo de una por otra. De hecho, Deleuze, en su Posdata, (1996 [1990]) señalará que la crisis de las instituciones de encierro se acompaña por una "administración de su agonía" y junto con Guattari piensan en la complementariedad de sujeción y esclavitud maquínica (ver III), lo que habilita a pensar diversos solapamientos entre ambas formaciones. Por supuesto, antes de poder hacer esas lecturas, es necesario abordar las tesis fundamentales que Deleuze y Guattari construyeron para pensar el capitalismo contemporáneo. 
Abordaremos los micro-agenciamientos massmediáticos encarnados por las máquinas informáticas y la televisión, pero subrayando la posibilidad de actualizarlos (como al respecto los han pensado Lazzarato, Berardi, entre otros). Al mismo tiempo, nos detendremos en la reterritorilización por engagement propia del agenciamiento de juego contemporáneo ${ }^{9}$ (los videojuegos) cuya presencia (a nivel de desarrollo, distribución y consumo) en América Latina es insoslayable (Gómez, 2014; Rossi, 2018a-b). Por otro lado, abordaremos lo que podrían ser llamados controlatorios de la computación ubicua, recorriendo ejemplos propuestos por otros pensadores contemporáneos y los articularemos con el capitalismo de plataformas cuya presencia en nuestra región ha sido estudiada por diversos investigadores ${ }^{10}$.

Por último, como se desprende de lo antedicho, el objetivo de este artículo no es simplemente informar al lector de una pesquisa clausurada, sino aportar elementos que permitan fundamentar una línea de investigación cuya potencia para pensar al capitalismo contemporáneo y su enraizamiento en el contexto latinoamericano es indudable. Así también, en nuestras conclusiones, nos preguntaremos más allá de las estratificaciones del agenciamiento sobre las líneas de fuga o desterritorializaciones de las formaciones sociales de control.

\section{Mutación epistémica y diagramática}

Ha sido ampliamente reconocido que en dos escritos ${ }^{11}$ de finales de su vida Deleuze (2008, 1996 [1990]) formularía la aparición del problema del control. No obstante, tal tesis se haría ya visible en las interpretaciones deleuzianas sobre la obra de Foucault en las que terminaría de gestar una hipótesis doble que anticipa las mutaciones en el capitalismo contemporáneo. En ellas sostendrá, por un lado, que las formaciones de saber encuentran un núcleo distinto a la forma-Hombre de la episteme moderna $\mathrm{y}$, por otro, que las relaciones de poder adquieren un diagrama o máquina abstracta de estratificación diferente al de las sociedades disciplinarias (ulteriormente, también ello señalará un plan) (Deleuze, 2013, 2014, 2015).

9. Esto no implica un total reemplazo de otras prácticas lúdicas, sino el rol preponderante para las formaciones del control de los videojuegos. Consultar Rossi (2018b) para una cartografía genealógica de estas prácticas en el contexto latinoamericano.

10. Pensamos aquí en la articulación con los ensayos críticos y estudios empíricos sobre el capitalismo cognitivo (informacional, de vigilancia, etc.) llevados adelante por investigadores latinoamericanos como Míguez (2013), Zuckerfeld y Zangaro (2011), Bruno, Kanashiro y Firmino (2010), Sibilia (2008), entre otros.

11. Nos referimos a la ponencia ¿Qué es el acto de creación? y a Posdata sobre las sociedades de control. 
Esta vía interpretativa que esboza el problema de un pasaje entre las sociedades disciplinarias y las sociedades de control, se hace cada vez más evidente en los escritos que prologan el réquiem a su amigo, pero sólo termina por aparecer en el Anexo del libro Foucault que compendia los cursos dictados entre 1985 y 1986. Así la mutación epistémica anuncia una progresiva aparición de procesos de racionalización analíticos evidenciados en el marco de la emergencia de saberes como la cibernética y el estructuralismo que exceden y provocan un sobrepliegue en el horizonte epistémico moderno y sus tres empiricidades (la vida, el trabajo, y el lenguaje) (Deleuze, 1987b, 2013, 2014). Como han subrayado otros autores, esta transformación en la episteme se hace evidente bajo el problema de la noción de información en las ciencias contemporáneas, así como en la aparición de un cúmulo de objetos limítrofes (como comunicación, sistema, organización, etc.) que se convierten en el basamento de distintos saberes (Rodríguez, 2010a). Desde posiciones complementarias, pensadores argentinos como Pablo Rodríguez y Sebastián Rigotti han ampliado la lectura deleuziana mientras que, en el plano internacional, este problema fue trabajado por Sfez y, luego, por Stiegler como épistémè numerique.

Ahora bien, de acuerdo con la interpretación deleuziana, los signos de esta transformación en las formaciones de saber, en la primera mitad de la centuria pasada, para Foucault, se harían evidentes en un lenguaje que se reagruparía bajo una potencia nueva que no se ocuparía de la representación-significación. Sin embargo, Deleuze (2014 y 1987b) es tajante y no coincide con su interpretado en otorgar al lenguaje un privilegio para leer los quiebres epistémicos que no residiría en las restantes dimensiones empíricas de la finitud. De hecho, ampliará la hipótesis foucaultiana, sosteniendo el advenimiento de un nuevo momento del pensamiento. Para Deleuze la nueva forma epistémica de la combinatoria finita e ilimitada (o superhombre), tendría su correlato, por un lado, en una fuerza de agrupamiento de la vida que se desprendería de la biología (evolutiva) hacia la biología molecular (una suerte de revancha del código genético sobre el organismo). Pero también, por otro lado, Deleuze ${ }^{12}$, nutriéndose de las anticipaciones de Guattari (2017), sostendrá que el trabajo, desprendido de la economía política, se reagrupará "en un ser bruto del trabajo: son las llamadas máquinas de tercera generación" (Deleuze, 2014:338) que conforman nuevos sistemas hombres-máquinas. Así, ya para mediados de 1980, el filósofo francés ponía en el centro de las transformaciones de las fuerzas en el hombre a los agenciamientos de máquinas cibernéticas e informáticas. Estas incluían a las tecnologías de las imágenes, por ello les advertía a sus estudiantes que, al entrar en contacto con los ordenadores, sus fuerzas existentes se componían con otras fuerzas ${ }^{13}$. Se trataba de las fuerzas del silicio (filum) que venían de formaciones sociales que conformaban el Afuera de las sociedades disciplinarias.

12. Así ya en Diálogos, Deleuze y Parnet (1980) posaban la mirada en la potencia de la máquina abstracta de la informática para llevar a cabo una molecularización del poder de control.

13. Para Deleuze aquello que entra en composición con las fuerzas en el hombre (concebir, recordar, querer e imaginar) son fuerzas de un finito ilimitado de combinaciones. 
Detrás de esos nuevos enunciados de las formaciones de saber, está tematizada la muerte de la forma-Hombre, objeto y sujeto del saber, para en el análisis foucaultiano devenir sujeto político de las formaciones disciplinarias. Por ello, en sus clases Deleuze insistirá en que si la forma-Hombre no es el hombre en tanto se conceptualiza, sí encarna un modo de existencia. Es decir, excede el terreno de la arqueología del saber, señalando para Foucault, necesariamente, un cambio de eje problemático hacia la genealogía del poder. Así, la figura del Hombre en el poder disciplinario no será vista sólo como producto epistémico, sino que se presentará como el correlato de un poder sobre la vida (biopoder), articulado en anatomopolítica (técnicas disciplinarias de normación del cuerpo máquina) y biopolítica (normalización del cuerpo-especie). De allí que para los autores el humanismo será un elemento clave en la generación de eficacia económica disciplinaria o, en los términos de Mil Mesetas, implicará una forma-Estado apoyada en la eficacia del modo de semiotización de la Rostridad del régimen de signos significantes.

Siguiendo ese hilo conductor, en sus clases, Deleuze indicará el nacimiento de una tercera formación histórica, que comienza en el siglo XIX y que se extiende en el XX: sobre las disciplinas en crisis se montaría un poder de control. Como es sabido, esta es la hipótesis que un lustro después seguirá expresamente en su Posdata. Donde se hace evidente una mutación diagramática o de las relaciones de fuerzas. Pues entre ambos ejes el diagrama o, en la acepción de Mil Mesetas, la máquina abstracta ${ }^{14}{ }^{15} \mathrm{de}$ las relaciones de fuerzas constitutivas del poder saltará de imponer una tarea a una multiplicidad poco numerosa en un espacio cerrado a controlar los acontecimientos principales de una multiplicidad numerosa en un espacio abierto u otra manera de controlar, en cada momento, una población (sin que esta categoría se reduzca a realidades humanas).

14. Debe recordarse que en la teoría social deleuzoguattariana se denomina de esta forma al proceso de doble articulación o individuación de los agenciamientos sobre un eje vertical.

15. En la nota anterior destacamos la cualidad de social, pues, como ha sido señalado por los evaluadores del presente, el hecho de comprender a la teoría deleuzoguattariana en el universo de las teorías sociales implica discusiones ontológicas, políticas y epistemológicas que, por cuestiones de espacio, no pueden ser incluidas en este escrito. No obstante, señalemos que varios de dichos ejes son recuperados en Brown (2009), quien apunta, a través de ¿Qué es la Filosofía?, el hecho de que Deleuze y Guattari no atribuyen una tarea afirmativa de creación conceptual, de funciones, o de perceptos y afectos a las Ciencias Sociales y, desde allí, esgrime su crítica sobre la teoría de los ensamblajes de DeLanda. Por ello, Brown intentará recuperar esa tarea constructiva para integrar a Deleuze y Guattari en el campo del conocimiento social (excediendo los límites de nuestro trabajo). Para nosotros es posible predicar social de la teoría deleuzoguattariana cuando ambos autores analizan, específicamente, las relaciones entre deseo y poder (agenciamientos y dispositivos) en formaciones sociales concretas. Este supuesto se confirma, por ejemplo, cuando Deleuze (2014 [1986]:44) subraya que "[l]os agenciamientos sociales son mezcolanzas [y] estrategizan por todos lados", al tiempo que como método (tardeano-foucaultiano) para la sociología alienta a tomar un dispositivo concreto y definir cuál es el grado de efectuación del diagrama de fuerzas de un campo social. 
Por ello, en consonancia con el marco amplio de las prácticas de gobierno de multiplicidades en espacios abiertos y de las tecnologías del ambiente, Foucault anuncia una categoría que estará en el corazón de las sociedades de control tal como las piensan Deleuze y Guattari: "La población (...) es por un extremo la especie humana y por otro lo que llamamos público" (Foucault, 2006: 39). De allí que Lazzarato proponga que el concepto de vida, ahora bajo la noción de público, se ampliaría hasta abarcar la atención, la memoria, y el cerebro, por lo que, al lado de la biopolítica, nacería, hacia finales del siglo XIX, una noo-política (Rodríguez, 2010b). Esta nueva grilla de gubernamentalidad permite ver que la finalidad del diagrama de poder en las sociedades de control ya no es sustraer (soberanía), ni combinar y aumentar la potencia de las fuerzas (disciplina), sino efectuar y producir mundos normalizados (de consumo, información, opinión, trabajo, ocio, etc.). En otros términos, estratificar ciertos agenciamientos territoriales como los que surgirán de la combinación entre los medios masivos de comunicación.

Para Lazzarato (2006) en esos mundos vaciados de toda singularidad, donde la producción de subjetividad está ligada a una libertad ejercida sólo como elección entre posibles (construidos por el marketing, la publicidad, etc.), el capitalismo contemporáneo logra neutralizar la dinámica de efectuación del acontecimiento ${ }^{16}$, modulando las acciones posibles mediante tecnologías semióticas de acción a distancia a través de signos (cine, televisión, Internet, etc.). Se trata, como lo señalarán Guattari $(2015,2017)$ y Berardi $(2007,2009)$, de técnicas de control semiótico que modulan la invención operando sobre la memoria y la atención y extendiéndose hacia modos de semiotización que el poder disciplinario sólo soñaba con taponar, acallar, someter, etc. Así se produce un cambio radical en las formas de organización del poder y sus modalidades de ejercicio que giran alrededor de la modulación de los procesos de subjetivación en espacios abiertos.

Por otro lado, en la misma Posdata, nuestro autor va a insistir en la necesidad de un "estudio sociotécnico de los mecanismos de control". Claramente, el problema se hace más complejo cuando se incorpora a la discusión a Guattari (aunque Brown no ilustre este punto) en quien el paradigma estético ciertamente iría a contramano del científico (social). No obstante, el contexto de producción del concepto de agenciamiento coincide con las investigaciones interdisciplinarias documentadas en Fourquet y Murard (1978) y esto deja huellas en un Guattari (2013) que sostendrá que los agenciamientos (y los equipamientos) dan al socius su consistencia real conectando modos de semiotización y de subjetivación. Como se observa, la relación entre Ciencias Sociales y la teoría deleuzoguattariana es un problema que excede al presente y ha sido trabajado en extensas compilaciones que no podremos discutir aquí pero que parten de supuestos similares a los nuestros (como las de Fuglsang y Sørensen). Asimismo, como Buchanan, creemos que los volúmenes de Capitalismo y Esquizofrenia constituyen un aporte fundamental a las teorías sociales críticas.

16. Como resume Badiou (en Zarka, 2010: 23) sobre la política deleuzoguattariana: "la sociedad de control es tan sólo la organización de la prohibición del devenir". 
Por supuesto, un lustro antes de sus cursos sobre Foucault, Deleuze y Guattari (1997) ya anticipan este problema sosteniendo que las formas de utilización del silicio y de la combinatoria finita e ilimitada no se restringirían a las formaciones de saber, sino que se expandirían al conjunto del campo social. La expansión, como puede leerse en La Revolución Molecular, va de la mano con sistemas de iniciación en los modos de semiotización del capitalismo que ya no pasarían por los grandes encierros disciplinarios (la escuela, el hogar familiar, el ejército, el hospital, la fábrica, etc.) sino por redes y conjuntos que molecularizan y miniaturizan el control a través de agenciamientos massmediáticos y controlatorios de la computación ubicua. Pero en Mil Mesetas el problema requiere de una tercera tesis para funcionar cabalmente: a la mutación epistémica y diagramática, le es concomitante la aparición de nuevos modos de subjetivación.

\section{Transformaciones en los modos de subjetivación}

En un curso preparatorio de Mil Mesetas que impartirá en 1979 en Vincennes, Deleuze (2017) hará una distinción fundamental para comprender el lugar central de los agenciamientos massmediáticos en las sociedades de control. Sostendrá que pueden distinguirse dos modos de subjetivación de la axiomática capitalista, por un lado, esclavitud, servidumbre o sometimiento maquínico (asservissement par la machine) y, por otro, sujeción social (assujettissement à la machine). En sus clases, Deleuze se aprestará a distinguir ambos conceptos desde un punto de vista técnico y uno económico.

Desde el punto de vista técnico, sostendrá que hay sometimiento o esclavitud maquínica cuando los hombres mismos son partes constitutivas de la máquina; es decir, la máquina se define como un conjunto comunicante de elementos humanos y de elementos no humanos (Deleuze, 2017). Se trata de la constitución de agenciamientos donde los elementos humanos y no humanos son partes integrantes en igual medida, ergo constituyen un conjunto de comunicaciones y de informaciones recíprocas. Así, el agenciamiento hombres-máquinas puede agrupar elementos mecánicos, energéticos, informáticos, etc. y cuando se imagina la situación del hombre en él, implica un sometimiento en o mediante (par) la máquina. Pero Deleuze advertirá que la noción de "asservissement" no guardará ningún sentido peyorativo, sino que es un nombre técnico que Guattari (2017) extrae de la cibernética y de la ergonomía ${ }^{17}$ y que se relaciona estrechamente con la noción de megamáquinas socio-técnicas de Mumford (2010). Así, esclavitud maquínica refiere a un modo de control y regulación de la máquina técnica y social como sistema de comunicaciones y no a un sistema de dependencia personal. Esclavitud pública y generalizada, no privada, subraya Deleuze (2017). Aquí podríamos hacer una anticipación y señalar, como sostienen Lazzarato (2014) y Stiegler (2015), que mientras la sujeción social produce individuos subjeti-

17. De hecho, Deleuze (2017), para conceptualizar los sistemas hombres-máquinas, se apoya en los desarrollos de Montmollin. 
vados, la esclavitud maquinica genera realidades dividuales y masas que se vuelven muestras para mercados y bases de datos para el cálculo intensivo. El curso continúa y Deleuze, para diferenciarla de la noción de esclavitud maquínica, sugiere que la sujeción social a la máquina (assujettissement) sucede cuando nos servimos de ella bajo las modalidades de producción o consumo.

Ahora bien, aquí nos importa uno de los ejemplos que recorrerá Deleuze (2017), inspirado en las anticipaciones guattarianas. Será el caso de la televisión pues permite observar la complementariedad del régimen de sujeción y el de esclavitud maquínica en el contexto de los agenciamientos massmediáticos. Al margen de la ya vetusta televisión en el centro del hogar, donde toda la familia se reunía y quedaba sujeta tras la voz del presentador (ACE), a partir de Bradbury, nuestro autor imagina un sistema donde la televisión se desplaza del centro de la casa a sus muros (AMC). Se trata de un muro-televisión cuya gran transformación se cifraría en que el programa variaría al mismo tiempo en que se alteraría la disposición del televidente. En los términos de su interpretación, en el ordenador central del broadcasting habrá lugar para pequeños ordenadores (los muro-televisores) y la audiencia se relacionará con la máquina de modo tal que el animador de televisión podrá dirigirse al nombre propio del televidente. La audiencia se ha vuelto parte constitutiva del programa mismo, un detalle que estará presente cuando analice la noción de inserción en torno a las imágenes y signos en la era del control. Al mismo tiempo, Deleuze señala experiencias de emisión alemana que empiezan a ser llamadas de "dilación" y cuyo centro lo constituye el eslogan "emita Ud. mismo". En un ejercicio de ciencia ficción anticipatoria diríamos que nuestro pensador descubre dos grandes plataformas: las redes telemáticas de los muro-televisores interactivos y el broadcast yourself. Pero no se trata simplemente de un cambio en las diversiones, sino de un pasaje del régimen de la sujeción social al de la esclavitud maquínica generalizada o, al menos, de la complementariedad entre ambos impulsada por micro-agenciamientos que tienen en la base a las máquinas de tercera generación:

"Si las máquinas motrices han constituido la segunda edad de la máquina técnica, las máquinas de la cibernética y de la informática forman una tercera edad que recompone un régimen de esclavitud generalizada: "sistemas hombres-máquinas", reversibles y recurrentes, sustituyen a las antiguas relaciones de sujeción no reversibles y no recurrentes entre los dos elementos; aparece una nueva esclavitud, al mismo tiempo que el régimen de trabajo cambia, que la plusvalía deviene maquínica y que el marco se extiende a toda la sociedad. (...) Recientemente se ha subrayado hasta qué punto el ejercicio moderno del poder no se reducía a la alternativa clásica "represión o ideología", sino que implicaba procesos de normalización, de modulación, de modelización, de información, que se basan en el lenguaje, la percepción, 
el deseo, el movimiento, etc., y que pasan por microagenciamientos. Este conjunto implica a la vez sujeción y esclavitud, llevadas a los extremos como dos partes simultáneas que no cesan de reforzarse y alimentarse la una de la otra. Por ejemplo: se está sujeto a la televisión en tanto que se la utiliza y consume, en esa situación tan particular de un sujeto de enunciado que se toma más o menos por sujeto de enunciación ("ustedes, queridos telespectadores, que hacen la televisión..."); la máquina técnica es el medio entre dos sujetos. Pero se está esclavizado por la televisión como máquina humana en la medida en que los telespectadores son, ya no consumidores o usuarios, ni siquiera sujetos capaces de "fabricarla", sino piezas componentes intrínsecas, "entradas" y "salidas", feedback o recurrencias, que pertenecen a la máquina y ya no a la manera de producirla o de utilizarla. (...) Nosotros tenemos el privilegio de padecer, a través de las mismas cosas y de los mismos acontecimientos, las dos operaciones a la vez. Sujeción y esclavitud, más que dos estadios, forman dos polos coexistentes". (Deleuze y Guattari, 1997: 463).

Desde el aspecto económico, Deleuze y Guattari leen los Grundrisse a partir del marxismo autonomista italiano (principalmente en conjunto con los escritos de Negri). Así llegarán a lo que se conocerá luego como la tesis del General Intellect. Por ello también describirán la distinción entre sujeción social y esclavitud maquínica como arraigada en el equilibrio entre capital constante y capital variable. El capitalista, para Deleuze y Guattari (1997), jamás confunde máquinas y hombres. Es un "humanista" de la primera hora, pues encuentra en el capital variable la fuente de la plusvalía.

Así, todo parece marchar ajustadamente entre forma-Hombre, capitalismo industrial, Estados nacionales y dispositivos disciplinarios. No obstante, la tendencia histórica y alarmante del capitalismo (que deviene axiomático) es dar mayor relevancia y crecimiento al capital constante sobre el variable. La industrialización no se detiene con las grandes fábricas, sino que iniciará procesos de automatización donde el trabajador pasa a ser adyacente al proceso de trabajo. Asimismo, el trabajo, separado ya de la actividad libre y recortado a partir del sobretrabajo, en la conjunción cualitativa y tópica de los flujos descodificados que inauguraban los Estados Nacionales, tomará una nueva forma. Será informal, trabajo precario y flexible y tendrá, a juicio de Deleuze y Guattari, un rol central en la nueva economía mundial (Sibertin-Blanc, 2013) y, como han demostrado innumerables estudios sociales, para América Latina.

De hecho, Deleuze (2014) advierte tempranamente a sus estudiantes que quedarían absolutamente expuestos a nuevas culturas del trabajo recapturadas y reformuladas por la axiomática capitalista. Puesto que, por esa vía de análisis económico, el filósofo francés llega a una fórmula que le permite evaluar otro punto de pasaje entre las formaciones sociales disciplinarias y las del control: el valor de la sujeción social está en directa relación con el crecimiento de la importancia del capital variable (el sala- 
riado) respecto del constante y, viceversa, la esclavitud maquínica será directamente proporcional a la importancia del capital constante en la economía. Esto es, cuando la plusvalía deja de estar atada al régimen productivo en una escala humana (aquella que se forja como contrapartida de la sujeción) y se ajusta a los tiempos y espacios de los procesos de automatización, surgen formas de producción que hacen indistinguibles el trabajo del sobretrabajo y del desempleo; y, a su vez que, paradójicamente, extienden la valorización del capital a todo el cuerpo social. Para Deleuze y Guattari (1997) si la sujeción social del salariado tendrá como correlato una mecánica de las fuerzas que posibilita la traducción de toda actividad libre a trabajo posible, con el régimen capitalista axiomático instalado, la plusvalía se vuelve universal y maquínica haciendo que el sobretrabajo fagocite toda actividad libre:

"[S]e diría que la alienación humana ${ }^{18}$ ha sido sustituida en el propio sobretrabajo por una "esclavitud maquinica" generalizada, de tal forma que se proporciona una plusvalía independientemente de cualquier trabajo (el niño, el jubilado, el parado, el telespectador, etc.). No sólo el usuario como tal tiende a devenir un empleado, sino que el capitalismo no actúa tanto mediante una cantidad de trabajo como mediante un proceso cualitativo complejo que pone en juego los modos de transporte, los modelos urbanos, los medios de comunicación, la industria del ocio, las formas de percibir y de sentir, todas las semióticas ${ }^{19}$ " (Deleuze y Guattari, 1997: 499).

Así, la teoría deleuzoguattariana colocaba, ya a comienzos de la década de 1980, en el centro de su crítica, a los procesos cualitativos complejos de los agenciamientos massmediáticos y a la "industria del ocio" como generadores de plusvalía maquínica para nuevos modos de subjetivación nacientes en el CMI. En paralelo, también anticipaba cambios en las formas de imaginación propiciadas por la gubernamentalidad contemporánea, así como la posibilidad de nuevas luchas.

18. Aunque Stiegler (2015) prefiere no recuperar desde aquí el problema del asservissement machinique, se trata de la misma idea cuando refiere a sociedades automáticas sin trabajo asalariado. De allí sus consideraciones sobre saberes que exceden las retenciones terciarias proletarizadas por la economía 24/7.

19. A partir de allí Deleuze y Guattari comienzan a pensar que los medios de la explotación, el control y la vigilancia se inscriben ahora, sutilmente, en las líneas moleculares y con ello, podríamos decir, suscitan órdenes semióticos pre-significantes o intensivos. 
Ahora bien, más arriba hemos señalado partes del curso sobre el poder en Foucault y de Mil Mesetas, donde Deleuze revisita la distinción entre las tres edades de la técnica que, convencionalmente, ha sido leída desde la Posdata. En esta composición tripartita se esconde también la división entre sujeción y esclavitud. La sujeción es una técnica moderna (en el sentido de tecnología de poder) y se completa con las máquinas de comienzo del capitalismo industrial (las grandes máquinas termodinámicas). No obstante, la sujeción no es un invento del capitalismo pues, para Deleuze y Guattari (1997), pertenece a un régimen semiótico específico, llamado significante o de la interpretación-significancia, propio del diagrama de las relaciones de fuerzas (o máquina abstracta) que llaman Rostridad. Se trata de un operador semiótico de los procesos de estatalización que es anterior a la descodificación generalizada de los flujos. Pero para los autores será el capitalismo el que lo lleve a su perfección, pues provee su factor económico correspondiente: en la cima de la sujeción, aparece el régimen del asalariado y la esfera de lo privado. En dicho régimen, el hombre será sujetado a la máquina por el capitalista que es el propietario privado (Rossi, 2017). Pero con la axiomática capitalista, los ritmos de producción ya no permiten la reproducción de la fuerza de trabajo, sino que tienden a asegurar sólo la finalización del producto y el trabajo por proyectos, donde el salario, como la deuda, quedarán presos de una constante modulación ${ }^{20}$.

En su gusto por quebrar las fronteras entre semiótica y política, Deleuze y Guattari sugieren que los Estados modernos proporcionarán lo que llaman modelos de realización de una axiomática mundial independiente. Esta axiomática es contraparte de otras formaciones sociales que denominan organizaciones internacionales o ecuménicas y que no esperan al capitalismo para funcionar (ven en los movimientos artísticos y en la religión monoteísta antecedentes). En otros términos, los Estados nacionales que describirán en Mil Mesetas (social-democráticos, totalitarios-anarcocapitalistas, centrales o periféricos ${ }^{21}$, burocrático-socialistas, etc.) tienen por función moderar la desterritorialización del capital ofreciendo reterritorializaciones compensatorias (Patton, 2013). Pero, sutilmente, los autores anticipan que la sujeción social estará más ligada a los modelos de realización (Estados modernos) que a la axiomática, pues, como dijimos, ésta última restaurará la esclavitud maquínica generalizada bajo novísimas formas técnicas y económicas. O, mejor dicho, la moderna formaEstado y la axiomática funcionarán en conjunto (de allí que nada les parezca más absurdo que la idea de un super-gobierno mundial).

20. De acuerdo con Deleuze (1996: 284) en el nuevo capitalismo: "La familia, la escuela, el ejército, la fábrica ya no son lugares analógicos distintos que convergen hacia un propietario, Estado o potencia privada, sino las figuras cifradas, deformables y transformables, de una misma empresa que sólo tiene administradores."

21. Deleuze y Guattari, como puede seguirse en Rossi (2017), consideran el ascenso del neoliberalismo en América Latina para estructurar la concepción de los Estados anarco-capitalistas. 
Pero, a diferencia de la sobrecodificación trascendente efectuada por la máquina significante (Rostridad) y, en parte, de la sujeción de los Estados modernos, los axiomas del capitalismo para los autores no serán meras fórmulas ideológicas sino enunciados operatorios (formas de expresión) que constituirán la forma semiótica del capital y que entrarán como partes componentes e inmanentes de los agenciamientos de producción, circulación y consumo. Ello para Guattari (2009, 2013, 2015), así como para Lazzarato (2006, 2014), Genosko (2009, 2012, 2016) y Norambuena (en Guattari 1998) constituye el objetivo del CMI, Cognitivo (Boutang, 2007) o semiocapitalismo (Berardi, 2007, 2009, 2013), en tanto la producción se centra en signos y en modos de subjetivación, donde la información adquiere un rol central.

En esta intertextualidad, Deleuze (1996 [1990]) diferencia entre el lenguaje de las disciplinas como analógico y el del control como numérico (y digital), teniendo como base su distinción entre forma-Estado y axiomática capitalista. De hecho, subrayará que el lenguaje disciplinario es analógico porque funciona en diferentes agenciamientos colectivos de enunciación (del padre, del jefe, del sacerdote, del propietario, del policía, de la maestra, etc.), que nos devuelven una mirada subjetivante del centro de poder y de la división de los sujetos en el régimen significante (del enunciado y de la enunciación). Ese centro funciona por resonancias a través de círculos concéntricos que permiten disponernos para comprender cada nuevo encierro, aún si siempre parecen un comienzo absoluto. Ahora bien, el lenguaje de las modulaciones del control es numérico y digital. Aquí lo que está en juego es algo que no es del orden de las líneas molares que aseguraban significancia, representación e interpretación, sino otro modo de semiotización. Pero, como dijimos, se trata de una teoría que elaboran a lo largo de dos décadas, por ello se suceden caminos confusos que vale la pena articular. Por un lado, Guattari (2013, 2017) nos ofrecerá su visión de aquello que Deleuze, en Diálogos con Parnet, hacia 1977, ya había esbozado: en la mutación contemporánea del capitalismo hay una tendencia a la molecularización del control. Pero, por otro lado, esa molecularización deberá apoyarse en una mayor dominancia de semióticas o de regímenes de signos e imágenes que van más a allá de la sujeción social y que ambos autores caracterizan, como veremos en el quinto apartado, como la confluencia entre semióticas pre-significantes y a-significantes. Allí es donde en la Posdata podrá leerse uno de los aspectos de la noción de dividual.

Siguiendo a Lazzarato (2014), se puede decir que en este doble régimen de subjetivación que tenemos el "privilegio" de habitar, la sujeción produce sujetos individuados con representaciones segmentarizadas a través de líneas molares (identidades, sexos, profesiones, nacionalidades, etc.) así como de roles jerarquizados (capitalistaobrero, burócrata-funcionario, trabajador-consumidor-desempleado, hombre-mujer, maestros-estudiantes, blancos-negros, etc.) y derechos de propiedad y decisiones económicas (que devuelven la imagen de racionalidad). La sujeción, que opera aún en 
el régimen significante, une la esclavitud maquínica a roles, lugares y funciones en las que los individuos se alienan a través de discursos (son unidos a una división social del trabajo), narrativas y significaciones que captan la subjetividad sólo al nivel de la representación y la conciencia (Genosko, 2009, 2012; Guattari, 2013, 2015). Se producen así sujetos individuados, cuyo último personaje, en el neoliberalismo, es el emprendedor de sí, propio del capital humano (Foucault, 2007). Este homo oeconomicus al actuar libremente se inscribe en una curva estadística y a través de esa inscripción el poder aparece, en su sutileza microfísica, como acción sobre otra acción real o posible: una modulación o una propagación transductiva regulada (Deleuze, 2014; Castro-Gómez, 2010). Para nosotros este homo oeconomicus es un punto de apoyo central de la sujeción social-esclavitud maquínica contemporánea y sus efectos, aunque aquí no podremos entrar en detalles, son legibles directamente en el trabajador cognitivo en el marco de la gubernamentalidad contemporánea (como en el contexto latinoamericano ha sido estudiado por Míguez (2013) y Zangaro (2011).

Al mismo tiempo, la esclavitud maquínica, de acuerdo con Lazzarato (2014), es un modo de subjetivación definido por sus mismas tendencias des-subjetivantes ${ }^{22}$, es decir, por su capacidad de desmantelar al sujeto individuado a través de actuar directamente a niveles preindividuales o suprainidividuales sin reconocer diferencias entre humano y no humano, palabras y cosas, sujetos y objetos (algo que las teorías críticas contemporáneas no alcanzan a reconocer ancladas en un nuevo logocentrismo). Este modo de subjetivación se da a nivel molecular, produce operaciones, induce a la acción y constituye inputs y outputs de una máquina a un tiempo social y tecnológica. Así, de acuerdo con Lazzarato, mientras que la sujeción produce individuos subjetivados, la esclavitud maquínica produce lo dividual configurado por masas y bancos de datos e informado por el poder de cálculo intensivo que, a juicio de Rouvroy, gesta una gubernamentalidad ${ }^{23}$ algorítmica. Lo dividual funciona en esta esclavitud maquínica como un conjunto de componentes no humanos de las máquinas técnicas inscripto en series de procedimientos y flujos semióticos desterritorializados. Ese componente dividual es la expresión de una máquina abstracta del poder que funciona en una vía diagramática (y no representacional); una tecnología de poder que debe ser separada de cualquier uso específico y que se dirige a multiplicidades en espacios abiertos.

22. Lazzarato prefiere, al tratar el problema del asservissement, referir a des-subjetivación por contraposición a las modalidades modernas de subjetivación (sujeción propietaria, proletaria, individual, liberal, etc.). No obstante, optamos por referirnos a dos tendencias de subjetivación (sujeción y esclavitud maquínica), pues si bien es cierto que se puede llamar a la segunda des-subjetivación con respecto al funcionamiento semiótico de la primera (Rostridad), no hay que olvidar que para Guattari la esclavitud maquínica guarda la virtualidad de procesos de devenir que permiten pensar en una subjetividad maquínica (ver conclusiones).

23. Los autores relacionarán directamente lo dividual con una gubernamentalidad neoliberal que completa el problema de la biopolítica. 
Concretamente, Guattari (2017) señalaba que las semióticas a-significantes están hechas de signos-puntos, signos-partículas o signos-fuerzas que actúan directamente sobre los flujos materiales: participan directamente de la generación de su objeto (Genosko, 2016). De acuerdo con Lazzarato (2014) su régimen no es el de las semióticas pre-significantes o intensivas que mezclan expresiones multidimensionales (como la danza o el juego) y tampoco es el del significante (en el cual cada signo refiere a otro mediante la representación a partir de operaciones de redundancia). Estas semióticas a-significantes que funcionan como forma y sustancia de contenido del agenciamiento, de hecho, apuntan más allá del registro semiótico pues la distinción entre signo y referente pierde su relevancia. Así, el régimen a-significante está constituido por fuerzas que conectan directamente los sistemas de percepciones y las actividades intelectuales a la fuerza de imaginar del maquinismo y al conjunto de procedimientos algorítmicos que pueblan el poder de modulación.

De esa forma, las semióticas a-significantes y las máquinas económicas, científicas, lúdicas en las que se enraízan, no nos enfrentan a modelos de producción social, política y económica del hombre para el hombre, sino a un inmenso filum maquínico que nos fuerza más allá del logocentrismo. Además, estas semióticas a-significantes y maquínicas operan en el vórtice del diagrama de control contemporáneo a través de lo que comprenderemos como reterritorializaciones por medios artificiales (ver V.).

\section{El poder del control y la modulación}

No obstante, estas figuras de la mutación epistémica, diagramática y en los modos de subjetivación no tienen sentido para Deleuze y Guattari sin los agenciamientos concretos que las ponen en marcha. Pues los axiomas del capitalismo son sus maquinismos, tal como lo expresa uno de los principios deleuzoguattarianos de definición de las formaciones sociales. Como anticipamos en la introducción, estos agenciamientos son siempre tetravalentes implicando tanto un eje de territorialización y desterritorialización (de las sustancias de expresión y de contenido), como un eje horizontal de codificación y descodificación (de las formas de contenido y de expresión).

Si volvemos a nuestro tópico podemos decir que en las sociedades disciplinarias la normalización es una forma de codificación, mientras que las disciplinas y los encierros se conforman como las territorialidades de la sujeción moderna. Sin embargo, en las sociedades de control, la codificación es del orden del molde variable. Se convierte en modulación dividual propia del conjunto de los sistemas de registros anticipatorios, bases de datos, patrones de conducta digital, etc. inscriptos en las componendas de la computación ubicua. Al mismo tiempo, la territorialidad se expresa en los micro-agenciamientos que componen reterritorializaciones artificiales. Sin ellos la modulación y las semióticas a-significantes (propias de la variedad, el volumen y la velocidad del Big data y del data mining) aún quedarían atrapadas en los regíme- 
nes de la sujeción. Entre ambos movimientos (modulación y reterritorializaciones artificiales) se conforman los controlatorios del CMI y despliegan toda la fuerza de la axiomática sobre la esclavitud maquínica.

De hecho, para Deleuze (1996 [1990]) señal de la crisis de las disciplinas será la aparición de operaciones de modulación como máquina abstracta del control, donde los moldes del encierro se vuelven variables y aquello que modulan oscila de continuo. Es una forma de normación (para Stiegler (2015) a-normativa) que corresponde a las operaciones de codificación que configuran el perfil de todo agenciamiento concreto. Aquí aparece una interpenetración de las dos tesis anteriores sobre los modos de subjetivación contemporáneos en diferentes modalidades. Pues Deleuze aborda los encierros disciplinarios como operaciones de moldeado y a los agenciamientos del control como modulaciones. En los encierros como moldes el individuo es, a un tiempo, (in)formado y ajustado a una norma mediante operaciones de codificación con un inicio y un final definidos en los que, al menos como en el ejemplo simondoniano del ladrillo de arcilla, se obtiene un sujeto/objeto individuado (cuerpos dóciles y productivos). Estos moldes producen, a su vez, un tiempo dividido en segmentos reconocibles y finales identificables. Ahora bien, crecientemente la modulación los reemplaza por entrenamientos sin fines precisos y una inscripción continua en una serie de actividades ilimitadas. Siguiendo a Savat (2013) podemos decir que mientras que la disciplina opera en el espacio, la modulación lo hace en el tiempo o en la velocidad; la primera se basa en la observación, mientras que la segunda tiene como base el uso de simulaciones. La disciplina tiene inicios y fines bien determinados, pero el poder de modulación, como codificación, tiene como mayor característica su incesante variación. El producto de la modulación ya no es un objeto definido, sino algo que no tiene forma acabada, es un objetil variable (Deleuze, 1989). Una curva procesual-estadística donde la operación de la máquina abstracta del control será la de anticipar patrones de acción a través del cálculo intensivo (Stiegler, 2015) y ya no la de dar forma a un objeto (modo de objetivación del sujeto).

Ahora bien, siguiendo los señalamientos de Deleuze y de Lazzarato, se podría distinguir al marketing como una vía de gobierno, expandida con la televisión, pero aquella sólo logra completarse con las plataformas digitales y las componendas de computación ubicua que funcionan a través de recolección, selección, análisis y venta de datos sobre comportamientos diversos (compras, hábitos de lectura, ropas, películas favoritas, juegos, glitches, etc.). Esa información perfilada constituye los inputs y outputs de sistemas hombres-máquinas, pues lo dividual tiene una existencia estadística controlada por máquinas y redes en patrones de comportamientos predecibles. Como dijimos, esa información opera por semióticas a-significantes que no tienen al sujeto individuado por referente y no implican para funcionar la conciencia y las representaciones. El individuo para el Deleuze de la Posdata, es identificado como una 
posición o parte de la masa, y está construido en base a binarismos (semiótica molar de la sujeción); mientras que lo dividual está sostenido por semióticas a-significantes que entran en variación dependiendo de las vicisitudes de la situación inmediata. De allí que Rouvroy y Stiegler (2015), por ejemplo, puedan sostener que esta permanente extracción de datos parece no afectarnos cuando modula lo real.

Así, el poder de modulación forma un componente esencial del diagrama de control: conectando directamente con el gobierno de poblaciones y del público (multiplicidades en espacios abiertos). Pero, en lo fundamental, los agenciamientos contemporáneos de la modulación noo-política o del control destilan todo un conjunto de dinámicas de registro, observación, seguimiento, análisis, vigilancia, anticipación, etc. Como dijimos, encontramos un ejemplo actual de estas operaciones de modulación concretizadas en organizaciones transnacionales pilares de la economía global digital: las plataformas ${ }^{24}$. Ellas son paradigmáticas en la extensión de la valorización del capital a todo el cuerpo social y conforman parte de la codificación de los agenciamientos o controlatorios de la computación ubicua. Según Snircek (2017), desde la crisis de 2008, como lo anticipó Guattari, el capitalismo se centra en el monopolio, extracción, análisis y uso de datos de las actividades de los usuarios a través de un conjunto de algoritmos que, de acuerdo con Cardon (2015), funcionan bajo principios de popularidad, autoridad, frecuencia, repetición, trazabilidad, etc. Este nuevo capitalismo de plataformas, cuya inscripción en América Latina ha sido abordado en estudios tan diversos ${ }^{25}$ como los de Sibilia (2008) o los debates de la Agenda Digital cepalina, está estrictamente ligado a otras acepciones del poder de control que no podemos trabajar aquí pero que fueron exacerbadas como, por ejemplo, el capitalismo de la vigilancia (analizado en nuestra región por Bruno, Kanashiro y Firmino,2010), el aceleracionismo y diversas modalidades de trabajo cognitivo digital (Míguez, 2013).

En ese mismo sentido, Stiegler (2015: 65), partiendo de la pregunta por los agenciamientos controlatorios como central para su aproximación organológica y farmacológica, a través de la metáfora de Boutang (2007), sugiere que las plataformas son las verdaderas apropiadoras de las externalidades positivas ${ }^{26}$ conformadas por el conjunto de las relaciones sociales para la sociedad automática del capitalismo 24/7 (Crary, 2013).

24. Así, las plataformas de publicidad (como Google, Facebook, etc.), de servicios en la nube (como Dropbox, Github, etc.), industriales o de logística (como Siemens), de apoyo y servicios (como Uber, Amazon, etc.) y de productos (como Spotify, Netflix, etc.) primero se establecen entre los usuarios y luego fundan sus actividades registrando sus datos, analizándolos y dirigiéndolos por procesos de cálculo intensivo en tiempo real.

25. Diversidad que se ve enriquecida en nuestra región por las múltiples publicaciones de ONG (sobre derechos digitales, big data, gobierno de redes, vigilancia, software libre, etc.).

26. Para indagar la extensión a todo el cuerpo social de la valorización del capital, Boutang (2007) plantea una metáfora según la cual el capitalismo cognitivo se sirve de las relaciones sociales o externalidades positivas (como la polinización), allí donde el capitalismo industrial sólo encontraba rédito en la comercialización del producto (como la miel). 
Para el filósofo francés la gubernamentalidad algorítmica como producción y cálculo intensivo de huellas o retenciones terciarias (gramatización), propias de una modulación que trabaja a la velocidad de la luz (semióticas a-significantes), hace necesario trazar una nueva categoría que ilustre que en el Leviatán electrónico se gesta una transdividuación de masas (crowds). Con este neologismo Stiegler aúna la noción de dividual deleuzoguattariana y la simondoniana de transindividuación para subrayar que las plataformas y las componendas de la computación ubicua suspenden, por el momento, la potencia de la tecnicidad para soportar nuevas relaciones colectivas fundadas en la potencia del devenir (o disparidad).

No obstante, estas operaciones semióticas de codificación del capital recombinante (Berardi, 2009) que exacerban la movilidad, la fragmentación y la modulación, corren en paralelo a nuevos regímenes de signos y de imágenes que Deleuze y Guattari, de forma separada pero constante, supieron adivinar y teorizar durante la década de 1980 y comienzos de los años 9o. Como dijimos, la esclavitud maquínica implica elementos que no son visibles desde las semióticas estratificadas de la Rostridad del significante y esto explica, a su vez, que en el sistema deleuzoguattariano la "fuerza de imaginar" se componga con el filum maquínico del silicio. Pero para comprender esta afirmación debemos completar las mutaciones señaladas en el apartado III.

\section{El nuevo régimen de las imágenes del control y las reterritorializaciones arti- ficiales}

Así, el poder de control apoyado sobre las operaciones de modulación, implica a su vez la hipótesis de una modificación en los modos de semiotización. Como los lectores atentos perciben, si bien en Mil Mesetas se nombran diversos regímenes de signos o modos de semiotización, los autores sólo tratan como tales al significante y al post-significante. Luego preferirán la noción de formaciones sociales. De ese modo cuando Deleuze describa el paso de formaciones sociales disciplinarias a las de control y Guattari el ascenso del CMI, la hipótesis parece conllevar la aparición de otros modos de semiotización. Por ello, los dos filósofos señalan pistas de una mutación epistémica y diagramática que implica un cambio igual de profundo en los regímenes de signos y de imágenes.

Deleuze intentó trabajar el nuevo régimen de las imágenes expresado en una evolución interna del cine que encontraría un medio en la televisión y en el desarrollo propio de los agenciamientos massmediáticos compuestos de imágenes electrónicas (lo que incluirá al video y a los ordenadores personales). En este cruce, Deleuze (1987a) no pierde de vista que el cine es un agenciamiento concreto con dos caras, contenido y expresión, en un proceso genético de individuación (doble articulación). Si admitimos esta interpretación del cine como agenciamiento, no es extraño que, ya en la conclusión de Imagen-Tiempo, señale que, a mediados del siglo pasado, termina 
de gestarse un régimen de imágenes distinto al del cine clásico que contribuye en hacer florecer nuevas creaciones artísticas en lo que será el cine moderno. Así, tanto contenido como expresión se modifican a través de nuevos autómatas configurados por máquinas cibernéticas e informáticas para un nuevo régimen de la imagen que emana de ellas (electrónica y digital).

Como destaca Bogue (2003) la televisión parece participar de las innovaciones en el cine moderno, en tanto su imagen electrónica es creada a través de un escaneo constante de líneas de píxeles, descubriéndose como verdadera imagen-tiempo (presentación directa, mas no en el sentido de temporalidad pura). Con ella y, más tarde, con los procesos de digitalización surge una suerte de mutabilidad esencial de las imágenes permitiendo que sean duplicadas, simuladas o transferidas en una circulación continua sin claro origen, ni destino final. Deleuze (1987a) sostiene aquí que, como resultado, las imágenes de televisión ya no tienen exterioridad o un fuera de campo genuino (así como tampoco se interiorizarían en un Todo). En cambio, poseen un derecho y un revés que las hace reversibles, superponibles y prestas para una reorganización perpetua donde una nueva imagen puede nacer de cualquier otro punto. Con ello, para el filósofo francés, es como si los modelos de la ventana o del cuadro hubiesen sido sustituidos por una superficie opaca, horizontal e incunable, donde se inscriben datos que suponen "una legibilidad que no implica un lenguaje sino algo parecido a un diagrama" (Deleuze 1996: 46). La imagen video-electrónica se vuelve un verdadero tablero de información y, de acuerdo con Bogue, una pantalla cerebral ( $y$ en este sentido una versión de la moderna noosfera del cine). Pero esa inscripción de información no se da en el vacío, sino en el marco de la esclavitud maquínica. De allí que Deleuze sostenga que antes que una invención artística, el nuevo régimen parecerá responder a una función social.

Luego, en al menos dos oportunidades Deleuze $(1996,2014)$ sostendrá que al cine de preguerra (imagen-movimiento) le corresponde la noción de una alteridad soberana que se estructura a partir de la pregunta "¿qué es lo que hay que ver detrás de la imagen?" Mientras que al cine de posguerra (imagen-tiempo) se lo podría caracterizar como guardando una intención pedagógica (disciplinaria) de enseñar a leer lo insistente en y sobre las imágenes bajo la pregunta “¿qué es lo que hay que ver en la imagen?" Por último, la masificación de la radio y la televisión, señalan el inicio de un nuevo régimen. En una carta a Daney, Deleuze explica algo que en la conclusión de Imagen-Tiempo no ha de quedar tan claro: el cine busca en la televisión y en el video un relevo para las funciones estéticas y noéticas. No obstante, la televisión adquiere para sí una función social que asfixia esa aproximación estética y da lugar al nuevo poder de posguerra: el control, tal como lo había previsto Burroughs. Ahora la pregunta del nuevo régimen de la imagen será "cómo insertarse o deslizarse en las imágenes?" Se trata de una serie limitada o un continuum que tendrá en su fondo siempre otra 
imagen, la del ojo del espectador controlado que se encontrará insertado en la imagen (algo que Daney llama inserage). Por ello la imagen electrónica y digital se le presenta al filósofo como un nuevo medio creado por los americanos para controlar las altas velocidades.

Deleuze, al menos hasta donde sabemos, no va más allá. Sin embargo, cuando esboza que el nuevo régimen de las imágenes del control o del silicio funciona a partir de semióticas pre-significantes, entra en una conversación solapada con Guattari. Dicho régimen, como se desprende de Mil Mesetas, refiere a imágenes, signos y símbolos definidos por su polivocidad y multidimensionalidad antes que por la linealidad del régimen de la interpretación-significancia. Se trata de un modo de semiotización fundamental para comprender la conversación implícita en la noción de esclavitud maquínica, pues para que este sistema hombres-máquinas funcione, para que puedan unirse flujos semióticos de órdenes tan diversos, debe aparecer una temporalidad propia que los una.

Ya desde finales de la década de 1970, como sostiene Genosko (2012), mirar televisión es para Guattari una experiencia intensa de reterritorialización propiciada por un ritornelo muy complejo que une diversos componentes de subjetivación frente al set; se trata de un motivo repetitivo y un magnetizador que se instala en cada escena. Así, el observador se convierte en una intersección fluctuante o una constelación de componentes heterogéneos y afectos incompletos, sostenidos por un ritornelo estabilizador que conjuga diferentes tipos de mundos (territorios existenciales y universos de referencia) en un acoplamiento que parece funcionar sin trabajar (Buchanan, 2015). De acuerdo con Genosko, los elementos sensorios de la fascinación de la pantalla, junto a la fuerza narrativa, arrastran al televidente (aunque sin pérdida de atención a los alrededores) y lo introducen en un escenario de materias abstractas como fantasmas que se desvanecen.

Así, si, por una parte, el problema de la comunicación entre bases de datos, era, de acuerdo a la fórmula deleuziana, imaginado por Guattari como el surgimiento de una subjetivación maquínica no antropológicamente perfilada; por otro, los sistemas hombres-máquinas del asservissement machinique serán concebidos por el autor de La Revolución molecular como un conjunto de reterritorializaciones por medios artificiales. Esto es, por una parte, las formas de expresión o vías de codificación de los controlatorios (III) se encuentran en el conjunto de semióticas a-significantes que funcionan a través de lo que para los autores trabajados son dinámicas similares al funcionamiento de las señales propias del procesamiento de datos a altísimas velocidades. Para Guattari ello quería decir que el nuevo régimen trabajaba a través de signos-partículas o puntos-signos cuyo funcionamiento maquínico elude la forma de representación propia de los regímenes anteriores. Se trata, como vimos, de un régimen de signos que produce resonancias maquínicas: funcionamiento. Pero también, 
por otra parte, para que podamos integrar los micro-agenciamientos del asservissement machinique, cuyo paradigma tanto Deleuze como Guattari encuentran en la televisión y en la extensión de imágenes electrónicas e informáticas, hemos de entrar en pequeños ritmos sociales que territorializan esos agenciamientos. Esta parte argumental de los autores es oscura, porque supone una relectura de la meseta $\mathrm{Del}$ Ritornelo en la que surge la posibilidad de nuevos regímenes de signos que acompañan a los significantes y post-significantes. Si quisiéramos ensayar una síntesis lo que podríamos señalar es que los micro-agenciamientos que componen el asservissement utilizan, a un tiempo, esas semióticas a-significantes o maquínicas conjugadas con las semióticas pre-significantes. Semióticas que, a menudo, nuestros autores llaman líneas moleculares o segmentarizables. Por ello, la especificidad del nuevo régimen de signos será la de soportar relaciones entre modos de semiotización intensivos o de la corporeidad y modos de semiotización a-significantes o conjuntos de signospartículas que actúan directamente sobre los maquinismos del filum maquínico del silicio y que sostienen los procesos de modulación.

Pero, al fin de cuentas, se trata justo del pasaje entre sociedades disciplinarias de los encierros y las sociedades del control generalizado, en el que, como señala La Revolución Molecular, lo que se pone en evidencia es la progresiva aparición de un modo de iniciación semiótico del capital que no espera a las instancias de los aparatos de sujeción para comenzar. Han pasado los tiempos, dice Guattari (2017: 310-311), en los que se amenazaba al adolescente con el servicio militar:

"AAhora no podemos esperar tanto tiempo! La precocidad del adiestramiento infantil conlleva la puesta en práctica de nuevos métodos. Se impone cierta tendencia a recurrir cada vez menos a sistemas basados en la coerción material (...) y cada vez más a técnicas de impregnación audiovisual que realizan el mismo trabajo sin que se note apenas, con suavidad pero también en profundidad. Cuanto más temprana es la iniciación, más intensa y duradera será la impronta dejada por el control social."

Así, para Guattari (2004) el funcionamiento de la axiomática o la reestructuración del CMI implicaba un modo de intervención que reforzaba el control reticular de los medios de comunicación masiva, al tiempo que aceleraba la concentración maquínica e informática. De hecho, hacia mediados de la década de 1980, el filósofo francés abordará recurrentemente una amplia variedad de agenciamientos controlatorios en paralelo a sus viajes al corazón del CMI: Japón.

Como dijimos, Burroughs será, a un tiempo, inspirador del problema del control y explorador de las líneas de fuga de lo que Deleuze (2008) llamará comunidades de droga. Esto parece estar presente cuando Guattari (2007) proponga ampliar la noción de droga, suponiendo que todo lo que contribuye a proveer una sensación de perte- 
necer a algo, olvidándose de sí mismo (sujeción social) y entrando en procedimientos automatizables (esclavitud maquínica), es una suerte de estupefaciente. Entre ellos, los mecanismos de producción de subjetividad maquínica, drogas maquínicas, se hacen evidentes entre los japoneses que apreciaba como verdaderos locos por las máquinas. Pero no se refiere al dopaje como una mera analogía, sino que sostiene que estas actividades comprometedoras, atrapantes (engagement), incitan una explosión de endorfinas e intensos zumbidos maquínicos que involucran procesos que evitan la conciencia individual y gestan nuevos ritmos que soportan las reterritorializaciones de los agenciamientos controlatorios: "[E]l sujeto que regresa a su casa hecho pedazos, extenuado tras una jornada agotadora, y que pulsa mecánicamente el control de su televisor [ingresa en una] reterritorialización personal por medios totalmente artificiales" (Guattari, 2007: 58).

Para el filósofo francés estos fenómenos no se limitan al recurrente ejemplo televisivo, sino que incluyen a los videojuegos y a los pinballs. Por ello, para autores que recuperan a Guattari, como Galloway (2006), los videojuegos serán una alegoría paradigmática del control en las sociedades contemporáneas pues nos ponen en contacto directo con los regímenes de signos de la información, mientras que para DyerWhiteford (2015), las consolas de videojuego serán agenciamientos tecno-sociales que configuran subjetividades maquínicas, comandando la atención durante horas y postulando relaciones de comunicación e información entre jugadores, inteligencia artificial y colectividades en red con dinámicas que son propias del trabajo cognitivo. Desde América Latina, Gómez (2014) también pensó a los videojuegos como parte de un nuevo ludocapitalismo, algo que no es extraño si se considera (como puede leerse en Rossi, 2018a-b) el grado de penetración de estos agenciamientos (a nivel de la producción, la distribución y el consumo Míguez, 2013) en nuestra región.

No obstante, para Guattari y sus seguidores, estas reterritorializaciones son ambiguas pues tienen la capacidad de despertar un verdadero Eros maquínico cuyas consecuencias aún no están claras. De hecho, esta indeterminación estará en la base de la subjetivación de empresa de los jóvenes japoneses, pero también estará detrás de los italianos y de la movilidad de los estadounidenses que se han convertido en verdaderos campeones del dopaje maquínico. En todos ellos la subjetividad maquínica molecular se presenta como una suerte de retorno hacia vías individualistas que surgen ante el colapso de los movimientos de oposición ${ }^{27}$ y como el ímpetu detrás de sectores como Silicon Valley donde se produce una concentración de medios y de flujos semióticos y económicos que conformarán las megamáquinas del capital del conocimiento (disparando la esclavitud maquínica generalizada).

27. Cfr. con las subjetividades clasistas propias de lo que Guattari $(2013,2015,2017)$ consideraba los modos de subjetivación de las sociedades disciplinarias. 
En el mismo pasaje, Guattari sostendrá que la sociedad francesa no parece responder a esta forma de subjetivación maquínica (al menos hacia mediados de la década de 1980). En esta objeción nos da una pista central para comprender el argumento de la reterritorialización artificial de la subjetividad massmediática inscripta en la molecularización del control, pues en Francia para Guattari (2007:59): "Las superestructuras sociales son, por así decir, más bien molares. Apenas si hay entre nosotros instituciones que dejen lugar a los procesos de proliferación maquínica".

Como dijimos, el capital es un operador o una axiomática de flujos descodificados en busca de hacer confluir dominios heterogéneos en tanto que tales (esto es, sin sobrecodificarlos). Por ello, las reterritorializaciones por medios artificiales de los agenciamientos massmediáticos (como los videojuegos) expresan las más sutiles derivas del control efectuando el diagrama en forma de una progresiva molecularización; es decir, se montan sobre semióticas intensivas o de la corporeidad del nuevo régimen de signos y de imágenes ${ }^{28}$. Tal como especifica Guattari (2015: 284):

"En la edad del control generalizado, la modelización se hace más totalitaria y hegemónica. La producción de subjetividad ya no procede solamente por grandes conjuntos y por masas sino por una programación más molecular. El catecismo del nuevo dios software ya no se hace de boca en boca, sino directamente sobre las estructuras moleculares nerviosas y psíquicas -el niño que mama desde la cuna los esquemas pilotos que le son transmitidos por la tele y que modelizan tanto su percepción, su imaginario como sus valores de referencia; el obrero que está tomado en los engranajes de emplazamientos productivos asistidos por computadora, por comandos numéricos de todo tipo; los comportamientos del consumidor y del elector que son teleguiados en bucle de retroacción por la publicidad, los sondeos y la hipnosis televisiva. (...) la sociedad de control está dominada por una especie de pulsión determinista que, paradójicamente, no está por ello menos minada desde el interior por una imperiosa necesidad de preservar grados de libertad, de creatividad, de inventividad, en el ámbito de las ciencias, de las técnicas, de las artes, a falta de lo cual el sistema se desplomaría en una suerte de inercia entrópica."

28. En una investigación recientemente concluida, hemos señalado que estos procesos de (re)territorialización están relacionados a lo que en las prácticas de jugadores y de desarrolladores de videojuegos se denomina el engagement de la gameplay. Compromiso que es la base de la comunicación-información en los sistemas hombres-máquinas. La investigación rastrea tales procesos en las Global Game Jams de Argentina y señala que los componentes de esas reterritorializaciones conforman grandes ludotecas disponibles para que el cognitariado invente. 
De hecho, podríamos decir que la territorialización involucrada en estos microagenciamientos massmediáticos es cercana al problema que diversos comentaristas angloparlantes llaman engagement en diversas áreas (entre las que destaca el videojuego) y que trabajan sobre esas estructuras moleculares, psíquicas y nerviosas que señalaba Guattari (2009). Por ello no es extraño que esta situación que el filósofo francés imaginaba ya durante los años de invierno, para un conjunto de autores contemporáneos se concrete en las componendas de la computación ubicua que dan lugar a enunciados sobre la intimidad, la afectividad, la inmersión y el carácter intuitivo de la interfaz y de la interacción.

Así, en paralelo a la investigación de la modulación de las plataformas se podría intentar comprender la centralidad de los agenciamientos maquínicos de cuerpos propios de una fuerza de imaginar maquínica que guarda un carácter háptico-visual (ejemplarmente presentado por smartphones, tablets, etc.) o pertenece a un régimen de visibilidad-movilidad como el que destaca Verhoeff entramado en una nueva ecología de la atención (Citton, 2016). De allí que autores como Stiegler (2015) no dejen de enfatizar el carácter doble de la noción de digital: por un lado, como realidad numérica codificable y, por el otro, como semióticas de la corporeidad, intensivas o pre-significantes ejemplarmente concretizadas bajo las tecnologías háptico-visuales (digital para la punta de los dedos como ya señalaba Flusser). Así, si la modulación dividual especifica los ribetes socioeconómicos de la esclavitud maquínica, cuando empezamos a formar parte de sistemas hombres-máquinas, las reterritorializaciones artificiales de los ritornelos capitalísticos nos permiten comprender, en una dimensión socio-técnica, los procesos de esclavitud maquínica ${ }^{29}$.

\section{Conclusiones, líneas de fuga}

Por último, apuntemos, como hace Stiegler, que los problemas que nos deja la teoría social de Deleuze y Guattari han de ser trabajados desde diversos campos y deben tejerse alianzas con otras aproximaciones que permitan enriquecer sus planteos iniciales. Pero para ello las dimensiones que hemos mencionado en los párrafos anteriores han de ser pensadas como estrechamente ligadas, algo que, a menudo, no ha sido abordado en conjunto por los comentadores de la obra (y que, posiblemente, constituye un aporte de nuestro trabajo). Ellas implican, como dijimos, transformaciones epistémicas, diagramáticas, así como mutaciones en los modos de semiotización y en los modos de subjetivación que se hacen visibles en los agenciamientos controlatorios. De estos últimos hemos tratado de dar ejemplos que no buscan aplicar la teoría, sino reconstruirla y aumentarla con nuevos problemas para el análisis del capitalismo contemporáneo abordando el conjunto de agenciamientos concretos (AMC-ACE) propios de las formaciones sociales del control.

29. Ambas son indisociables de procesos de sujeción ligados a la gubernamentalidad neoliberal (Foucault, 2007). Pueden seguirse estos debates desde los estudios del pensador colombiano CastroGómez (2010). 
Como vimos, estos ejemplos encuentran eco en el contexto latinoamericano en una vasta red de investigaciones y autores. Por otra parte, aunque nos hemos detenido en las componendas de las plataformas digitales, las massmediáticos y las que pertenecen a la computación ubicua, también podrán buscarse y construirse otros ligados al régimen de trabajo cognitivo, a la formación permanente, a la medicalización y vigilancia de la población, etc.

Pero esta construcción teórico-empírica deberá tener en cuenta, además, el conjunto de líneas de fuga. Puesto que, por un lado, Guattari $(2013,2017)$ postulará recurrentemente como horizonte la posibilidad de gestar una subjetividad maquínica post-mediática y, por el otro, Deleuze $(1996,2008)$ subrayará la potencialidad de estas componendas para encontrar nuevas armas y crear un arte del control que haga fugar a los agenciamientos controlatorios. Ya que lo que a menudo se pasa por alto en las recuperaciones de los problemas del CMI es que, para nuestros autores, el poder se presenta como una afección del deseo. Esto es, las líneas de fuga son un dato primario de cualquier formación social, impidiendo que sólo en la lectura de las estratificaciones o racionalizaciones de las prácticas se acabe el análisis. No obstante, es claro que en la genealogía y en la cartografía de esas líneas dar cuenta de los procesos de regularización de las prácticas permite ver con mayor claridad las vías de desterritorialización posibles y cuáles son rápidamente recuperadas por el cuerpo lleno del capital. Entre las vías desterritorializantes quizás se descubre otro sentido de lo dividual, el que Deleuze a menudo cifraba como "le peuple manque" o la alianza entre estética y política.

Es que para Deleuze y Guattari la axiomática capitalista no conjugaba flujos descodificados sin que algo no escapase al mismo tiempo. De hecho, como dijimos, el fin del régimen del salariado y su constante crisis, lo llevan a pensar a Deleuze (2017) en un neoesclavismo, cuya figura central es la del trabajador temporario, en negro, el desocupado, etc. (como se evidencia en América Latina). Pero también guarda una potencialidad para engendrar líneas de fuga muy diversas (Rossi, 2017). Se trata de zonas o proposiciones indecidibles liberadas por la axiomática capitalista, proposiciones revolucionarias que inundan la potencialidad de los agenciamientos controlatorios, liberando en ellos líneas moleculares desterritorializantes. Es decir, que puedan ir más allá del diagrama de relaciones de fuerzas.

En el mismo sentido, de acuerdo a Genosko, en sus últimos escritos, Guattari incluye la posibilidad de una subjetividad maquínica que sea el punto de resistencia a estas nuevas capturas capitalistas. Aunque ya en Mil Mesetas pueden leerse como devenires liberados por la axiomática (devenir-electrónica, devenir-niño, devenirminoritario, devenir-molecular, etc.). Pues, para Guattari (1996, 20oo), en la era de la computación ubicua y planetaria, las máquinas y los humanos se han mezclado de tantas formas que podrían abrirse vías de exploración del potencial para la singularización creativa inmanente al vasto filum maquínico de los sistemas de redes globales 
que cubren el planeta. De allí que entre Mil Mesetas y Caosmosis, la noción de esclavitud maquínica encuentre una complementariedad con la posibilidad de forjar subjetividades maquínicas. Dicha potencialidad de las nuevas semióticas a-significantes y pre-significantes, de acuerdo con Martínez (2008), se debe a que la concepción de subjetividad de Guattari es plural, polifónica y transversal e intenta analizar en primer lugar los anclajes territorializados y las nuevas aperturas hacia lo que, en los últimos tramos de su obra, llamará universos de valor o incorporales. De allí que Guattari (2007) subraye que los procesos maquínicos, si pueden exceder el carácter marcadamente individualista en el que están encerrados, permitirán gestar un proyecto social que escape a los propios riesgos de toda droga o, en los términos de Mil Mesetas, evitar la generación de un cuerpo vidrioso y frágil como mera ilusión del Cuerpo sin órganos: "Esto es o el hundimiento lamentable, o la creación de universos insólitos. (...) los cristales residuales que constituyen las adicciones maquinicas podrían atravesar el planeta entero, reanimarlo, relanzarlo. Una sociedad aprisionada a tal punto tendrá que habérselas con esto, o perecerá" (Guattari, 2007: 60).

En la cita anterior se hace evidente que para Guattari las semióticas a-significantes, que pueblan los maquinismos de las sociedades contemporáneas, taponan y liberan las potencialidades de la esclavitud maquínica, encerrando nuevas posibilidades de desestratificación de los conjuntos molares. Se trata, como dijimos, de un acervo de proposiciones indecidibles de la axiomática que pueden servir de nuevas armas para desterritorializar las formaciones sociales del control y que encontrarían en experiencias concretas como las radios libres, películas independientes, emisiones televisivas y software interactivos que Guattari (2017) no dejaría de señalar, campos de exploración y lucha para la conformación de nuevos agenciamientos colectivos de enunciación en la construcción de sociedades post-mediáticas. Por ello, como hará Deleuze, Guattari no dejará de subrayar que será tarea de las jóvenes generaciones descubrir para qué se las usa y atisbar una salida.

\section{Referencias}

Berardi, Franco (2007). Generación post-alfa. Buenos Aires: Tinta Limón.

Berardi, Franco (2009). The Soul at work. Los Ángeles: Semiotext(e).

Berardi, Franco (2013). Félix. Buenos Aires: Cactus.

Bogue, Ronald (2003). Deleuze on Music, Painting, and the Arts. Nueva York : Routledge.

Boutang, Yann (2007). Le capitalisme cognitif. París: Ed. Amsterdam.

Bruno, Fernanda, Kanashiro, Marta y Firmino, Rodrigo (2010). Vigilância e visibilidade. Porto Alegre: Sulina.

Buchanan, Ian (2015). « Assemblage Theory and Its Discontents ». Deleuze Studies, 9(3): 382-392. 
Cardon, Dominique. (2015). A quoi rêvent les algorithmes. París: Le Seuil.

Castro-Gómez, Santiago (2010). Historia de la gubernamentalidad. Bogotá: Siglo del Hombre.

Citton, Yves (2016). «Subjectivations computationnelles à l' erre numérique ». Multitudes 1(62): 45-64. DOI: 10.3917/mult.062.0045

Crary, Jonathan (2013). 24/7: Late capitalism and the ends of sleep. Verso Books.

Deleuze, Gilles (1987a). La imagen-tiempo. Barcelona: Paidós.

Deleuze, Gilles (1987b). Foucault. Buenos Aires: Paidós.

Deleuze, Gilles (1989). El pliegue. Barcelona, Paidós.

Deleuze, Gilles (1996). Conversaciones. Valencia, Pre-textos. (1990) Pourparlers. Minuit.

Deleuze, Gilles (2008). Dos regímenes de Locos. Valencia: Pretextos.

Deleuze, Gilles (2013). El saber. Buenos Aires: Cactus.

Deleuze, Gilles (2014). El poder. Buenos Aires: Cactus.

Deleuze, Gilles (2015). Subjetivación. Buenos Aires: Cactus.

Deleuze, Gilles (2017). Derrames II. Buenos Aires: Cactus.

Deleuze, Gilles y Guattari, Félix (1997). Mil Mesetas. Valencia: Pre-textos.

Deleuze, Gilles y Parnet, Claire (1980). Diálogos. Valencia: Pre-textos.

Dyer-Whiteford, Nick. (2015). Cyber-Proletariat. Canadá: Pluto Press.

Foucault, Michel (2007). Nacimiento de la biopolítica. (1978-1979). Buenos Aires: FCE.

Foucault, Michel (2006). Seguridad, territorio, población. Buenos Aires: FCE.

Fourquet, François y Murard, Lion (1978). Los equipamientos del poder. Barcelona: Gustavo Gili.

Galloway, Alexander. (2006). Gaming. Minneapolis: University of Minnesota Press.

Genosko, Gary (2009). Félix Guattari. Londres: Pluto Press.

Genosko, Gary (2012). Félix Guattari in the Age of Semiocapitalism. Deleuze Studies. Edimburgo: EUP.

Genosko, Gary (2016). Critical Semiotics. Nueva York: Bloomsbury.

Gómez, Sebastián (2014). «Ludocapitalismo». En: AA.VV. Santiago de Chile: Primera Jornada de estudios en gubernamentalidad.

Guattari, Félix (1996). Caosmosis. Buenos Aries: Manantial

Guattari, Félix (200o). Cartografías Esquizoanalíticas. Buenos Aires: Manantial.

Guattari, Félix (2004). Plan Sobre El Planeta. Madrid: Traficantes de sueños.

Guattari, Félix (2007). «Los adictos maquínicos» en: Subjetividades para lo peor y para lo mejor. Restrepo, Carlos (ed.) Asociación de Investigaciones Filosóficas Medellín. 
Guattari, Félix. (2009). L'inconscient machinique. París: Recherches.

Guattari, Félix (2013). Líneas de fuga. Buenos Aires: Cactus.

Guattari, Félix (2015). ¿Qué es la Ecosofía? Buenos Aires: Cactus

Guattari, Félix (2017). La Revolución Molecular. Madrid: Errata naturae

Lazzarato, Maurizio (2006). Políticas del acontecimiento, Buenos Aires: Tinta Limón.

Lazzarato, Maurizio (2014). Signs and Machines. Los Ángeles: Semiotext(e).

Míguez, Pablo (2013) "Del General Intellect a las tesis del capitalismo cognitivo". Bajo el Volcán,13 (21): 27-57.

Mumford, Lewis (2010). El mito de la máquina. Logroño: Pepitas de Calabaza.

Pardo, José Luis (2011). El cuerpo sin órganos. Valencia: Pretextos.

Patton, Paul (2013). Deleuze y lo político. Buenos Aires, Prometeo.

Phillips, John (2006). “Agencement/assemblage”. Theory Culture and Society, 23(2/3): 108-109.

Rodríguez, Pablo (2010a). «Episteme posmoderna y sociedades de control». Margens, 6(7):23-38.

Rodríguez, Pablo (2010b). «El renacimiento de la biopolítica.». Tramas. (32): 6398.

Rossi, Luis (2017). «Deleuze: cartografía genealógica del capitalismo contemporáneo». CDyT 28(45): 195-201.

Rossi, Luis (2018a). «Un mapa de los estudios latinoamericanos y españoles sobre videojuegos». Observatorio (OBS*), 12 (1):147-168.

Rossi, Luis (2018b). «Apuntes sobre la relación entre agenciamiento de juego y máquinas». Lúdicamente, 13(7).

Rouvroy, Antoinette y Stiegler, Bernard (2015). «Le régime de vérité numérique. »Socio. (4): 113-140.

Sauvagnargues, Anne (2006). Deleuze. Buenos Aires: Amorrortu.

Savat, David (2013). Uncoding the Digital. Gran Bretaña: Palgrave.

Sibertin-Blanc, Guillaume (2013). Politique et état chez Deleuze et Guattari. París, PUF.

Sibilia, Paula (2008). La intimidad como espectáculo. Buenos Aires, FCE.

Srnicek, Nick (2017). Platform Capitalism. Nueva York: Polity.

Stiegler, Bernard (2015). La Société automatique: 1. L'avenir du travail. París : Fayard.

Zarka, Yves (2010). Deleuze, político. Buenos Aires: Nueva Visión.

Zangaro, Marcela (2011). Subjetividad y trabajo. Buenos Aires: Herramienta. 


\section{Sobre el autor}

Luis Sebastián Rossi es Doctor en Ciencias Sociales, Prof. y Lic. en Comunicación Social. Docente de grado en Teorías del Aprendizaje y TySC. Investigador FCEDU UNER. Becario CONICET. Correo electrónico es luissebastianrossi@gmail.com 


\title{
CUHSO. CULTURA-HOMBRE-SOCIEDAD
}

Fundada en 1984, la revista CUHSO es una de las publicaciones periódicas más antiguas en ciencias sociales y humanidades del sur de Chile. Con una periodicidad semestral, recibe todo el año trabajos inéditos de las distintas disciplinas de las ciencias sociales y las humanidades especializadas en el estudio y comprensión de la diversidad sociocultural, especialmente de las sociedades latinoamericanas y sus tensiones producto de la herencia colonial, la modernidad y la globalización. En este sentido, la revista valora tanto el rigor como la pluralidad teórica, epistemológica y metodológica de los trabajos.

\author{
EDITOR \\ Matthias Gloël \\ CoOrdinadora EDITORIAL \\ Claudia Campos Letelier \\ CORRECTOR DE ESTILO Y DISEÑADOR \\ Angélica Vera Sagredo \\ TRADUCTOR, CORRECTOR LENGUA INGLESA \\ Aurora Sambolin Santiago \\ Desarrollador de Sistemas \\ Laura Navarro Oliva \\ SITIO WEB \\ cuhso.uct.cl \\ E-MAIL \\ cuhso@uct.cl
}

LICENCIA DE ESTE ARTÍCULO

Creative Commons Atribución Compartir Igual 4.0 Internacional 